\title{
Proximate and organoleptic assessment of indigenous dishes based on pumpkin leaves, pulp and seeds (Cucurbita pepo)
}

\author{
Obiakor-Okeke Philomena Ngozi, Ogbonna Ikenna Chukwuemeka, Amadi Joy \\ Department of Nutrition and Dietetics, Faculty of Health Science Imo State University, Owerri, Imo State, Nigeria
}

Email address:

ngoziobiakor2001@yahoo.com (Obiakor-Okeke P. N.)

\section{To cite this article:}

Obiakor-Okeke Philomena Ngozi, Ogbonna Ikenna Chukwuemeka, Amadi Joy. Proximate and Organoleptic Assessment of Indigenous Dishes Based on Pumpkin Leaves, Pulp and Seeds (Cucurbita pepo). Advances in Biochemistry. Vol. 2, No. 5, 2014, pp. 65-70. doi: 10.11648/j.ab.20140205.12

\begin{abstract}
Introduction: The study evaluated the proximate composition of pumpkin (Cucurbita pepo) based on leaves pulps and seeds and organoleptic attributes of dishes prepared using pumpkin pulps seeds and leaves were also determined. Methodology: The samples used in the study include raw seeds, uncooked pulp, leaves, roasted seeds and cooked pulp were prepared for proximate analysis and also different native meals were prepared using leaves for soup, pulp for pottage yam and seeds for snacks for sensory evaluation involving 25 panelists using nine point heldonic scale, the result of sensory evaluation was subjected to analysis using ANOVA and DUNCAN test to compare the means. The proximate analysis were determined following standard methods and means and standard deviation of triplicate samples were determine. Result: The results of proximate analysis showed that protein composition ranged from $2.23 \%$ in cooked pulp to $29.65 \%$ in raw seeds, the carbohydrate from $4.86 \%$ in uncooked pulp to $14.08 \%$ in roasted seeds, the fat from $0.92 \%$ in uncooked pulp to $43.28 \%$ in roasted seeds and the ash from $1.18 \%$ in cooked pulp to $14.86 \%$ in roasted seeds. The result of sensory evaluation revealed that samples pumpkin pulp pottage (PPP), pumpkin leaves soup (PLS) and roasted pumpkin seeds (RPS) are significantly different $(\mathrm{P}<0.05)$ for colour, PPP were preferred more and RPS were the least preferred. PPP were preferred more and RPS were the least preferred in flavor. Samples PPP and PLS were statistically similar but significantly different $(\mathrm{P}<0.05)$ from RPS. Samples PLS are significantly different $(\mathrm{P}<0.05)$ from PPP and RPS for texture, PLS were preferred more and RPS were the least preferred in texture. Samples PPP and PLS are statistically similar but significantly different $(\mathrm{P}<0.05)$ from RPS in generally acceptability. Conclusion: The result of this study showed that pumpkin has high nutrient profile concentrated in the different edible parts; the seed, pulp and leaves and it is also generally acceptable. Therefore we recommend that the vegetable be incorporated into our daily meals and all the different edible parts be consumed for variety and for its nutrient content. We also recommend that more research be done to consider the other nutritional value like minerals, vitamins and phytochemical composition of the vegetables.
\end{abstract}

Keywords: Proximate, Organoleptic Assessment, Indigenous Dishes, Pumpkin (Cucurbita pepo)

\section{Introduction}

Pumpkin (Cucurbita pepo) belongs to the cuburbitaceae family that also includes gourds. It is quite similar to gourd in its appearance and is believed to have originated in North America. However, there is no fixed shape of pumpkin and the using vary from being oblate to oblong. Pumpkin has a high nutritional value and is associated with a lot of health and nutritional benefits. Pumpkin is an annual plant that is characterized by the presence of large and bristly leaves.
They bear large yellow and solitary flowers from which the fruit will eventually develop ${ }^{(1)}$.

Pumpkin requires a high temperature above $25^{\circ} \mathrm{C}$ during the growing period and fairly low humidity. It tolerates a range of soil conditions and some cultivars are tolerant to slightly acid soils ${ }^{(2)}$. The scientific name of pumpkin is cuembita pepo and belongs to the family cucurbitaceae. Its genus include Cucurbita digitata, Cucurbita ficifolia and Cucurbita maxima ${ }^{(3)}$. Pumpkin has an edible large, fleshly fruits. It can climb to $5 \mathrm{~m}$.

The seeds of many species in this plant genus Cucurbita 
are regarded as being very potent and effective de-worming agents that can easily paralyze and eliminate intestinal worms from the digestive system of a person. Among these useful species, the pumpkin itself is a primary example, the seeds or pepo of the pumpkin, derived from the name of the plant Cucurbita pepo L. are excellent against intestinal parasites. A similar action against intestinal parasites is also displayed by the seeds contained in the autumn squash called Cucurbita maxima Duchesne and of the Canadian pumpkin or cookneck squash, botanically called the C. moschata. This plant family has many cultivated varieties of plants used either for their food value or as herbal medicine ${ }^{(4)}$.

Pumpkin and other species of the Cucurbita family possess an unusual amino acid known as Cucurbitin, which has been chemically defined as 3-amino-3-carboxyprolidine. This is the main and most active chemical principle that is essentially the reason for the anti-helminthic (capable of eliminating worms) - activity displayed by the pumpkin remedy. The amino acid cucurbitin is found concentrated only in the seeds of the Cucurbita species of plants. At the same time, the concentration of this substance from the seeds of one individual plant to the other is very variable, even neither plants belonging to the same species, thus, there are varieties that tend to have a greater concentration of this useful compound. Note that the seeds of Cucurbita as teniafuge agent differ in variability in the chemical content of seeds in different species. In study, different samples of Cucurbita pepo shoed a cucurbitin content ranged from 1.77 to $6.63 \%$, the range of cucurbitin in the Cucurbita maxima species was from 5.29 to $19.37 \%$ and in the Cucurbita moshata, it ranged from 3.98 to $8.44 \%{ }^{(5-8)}$.

The oil of the Cucurbita seeds possess many types of these compounds, such as about $25 \%$ of the oleic acid and about $55 \%$ linoleic acid among other compounds. It has also been suggested that phytosterols present in the pumpkin seeds may play some role in the treatment of prostate problems ${ }^{(9)}$.

Pumpkin possesses some really top quality essential nutrients that are required for many processes in the human body and can serve as effective herbal medication. Pumpkin flesh is very low in calories yet contains abundant quantities of extremely good dietary fiber. Many important disease fighting nutrients are also found in large quantities in the flesh and pulp as well as the seeds of the pumpkin ${ }^{(10)}$.

Cucurbita pepo one of the varieties of pumpkin which is the one most common in the eastern part of Nigeria. Its indigeneous name is ("Ugboguru"), which is used in preparing some local dishes like soup, pottage yam and in making sauce. In making soup, the leaves are used to prepare (Ugboguru soup), while in making pottage yam, the pulp is scooped out after boiling for about $10-15$ minutes to be done. The pulp can also be used as source when it is scooped out after boiling and mixed with red oil, salt pepper and pounded onion. These mixtures can be used in eating boiled yam. It can also be eaten like that without boiled yam.

Cucurbita pepo leaves can be used to alternate other vegetables. The pumpkin seeds are roasted and eaten as snacks. The roasted seeds can be ground and used for food enrichment. Most people eat pumpkin seeds roasted but the seeds have the most nutritional value when eaten raw. To preserve many of the nutrients, they can be roasted at low temperatures (under $200^{\circ} \mathrm{C}$ ). Pumpkin seeds are moderate to very good source of a verity of nutrients, including minerals, protein and healthy fats. A couple handfuls of the seeds provide more than half of your daily dose of manganese, nearly half of your daily dose of magnesium and more than a quarter of your daily value of iron. They provide significant amount of dietary copper and zinc and quality protein ${ }^{(11-12)}$.

They also provide a significant amount of fat. However, it is the good, polyunsaturated kind, and they are rich in omega 3 and 6 fats which are believed to promote health and good cholesterol profile. The seeds of the pumpkin also contain nutrients called phytosterol and decrease the risk of some kinds of cancers. The seeds also contain L-tryptophan, a chemical that is thought to reduce stress and promote cal, and so the seeds have been used in studies of treating anxiety and other mood disorder ${ }^{(9,12)}$

The objectives of this study were to:

1. Determine the proximate composition of pumpkin pulp, seed and leaves.

2. Prepare traditional dishes based on pumpkin pulp, seed, and leaves.

3. Evaluate the organoleptic attributes of these dishes.

To bring to the knowledge of people the various recipes of pumpkin in both the indigenous and the foreign recipes and their preparation and cooking methods.

\section{Materials and Methods}

The pumpkin pulp, seed and leaves were purchased from Ogwumabiri Obizi market in Ezinihitte Mbaise Local Government Area of Imo State.

\subsection{Preparation of Samples}

The pulp was sliced open, the seeds were brought out. The flesh was scooped out and cut into tiny piece and kept in a cover container. The leaves were cut into tiny piece and stored also in a container. The seeds were ground in a manual grinder without drying. The roasted seeds were also ground in a different container covered air tight. The same was done for the cooked flesh from the pulp. All the samples were kept in a desiccators to preserve it from being contaminated.

\subsection{Proximate Analysis}

\subsubsection{Determination of Protein}

The protein content was determined by Kjeldahl method described by James ${ }^{(13)}$. The total nitrogen was determined and multiplied with the factor 6.25 to obtain the protein. Onehalf gram $(0.5 \mathrm{~g})$ of each sample was mixed with $10 \mathrm{mls}$ of concerned sulpheric acid AR Grade (Analytical Reagent Grade) in a Kjeldahl digestion flask. A tablet of selenium catalyst was added to it and the mixture was digested cheated under a fume cupboard until a clear solution was obtained in a separate flask. The acid and other reagent were digested but 
without sample to form the blank control. All the digests were carefully transferred to $100 \mathrm{ml}$ vol. flash using disliked water and made up to a mark in the flask. A $100 \mathrm{ml}$ portion of each digest was mixed with equal volume of $45 \% \mathrm{NaOH}$ solution in Kjeldahl distilling unit. The mixture was distilled and the distillate collected into $10 \mathrm{ml}$ of $4 \%$ Boric acid solution containing three (3) drops of mixture indication (bromocresol green and methyl red). A total of $50 \mathrm{ml}$ distillate was obtained and titrated against $0.02 \mathrm{MH}_{2} \mathrm{SO}_{4}$ solution. Titration was done from the initial green colour to a deep red end point.

The Nitrogen content were calculated as shown below:

$$
\% \mathrm{~N}_{2}=\frac{100}{\mathrm{~W}} \times \frac{\mathrm{N} \times 14}{100} \times \frac{\mathrm{vfT}}{\mathrm{va}}
$$

Where

$$
\begin{aligned}
& \mathrm{W}=\text { wt of sample analyzed } \\
& \mathrm{N}=\text { Conc. } \mathrm{H}_{2} \mathrm{SO}_{4} \\
& \mathrm{~V}=\text { Total volume of digest } \\
& \mathrm{Fv}_{\mathrm{a}}=\text { Volume of digest distilled } \\
& \mathrm{T}=\text { Titre value }- \text { Blank }
\end{aligned}
$$

\subsubsection{Determination of Fat Content}

Fat content of the samples were determined by the continous solvent extraction method using a Soxhlet apparatus. The method is described by Pearson ${ }^{(14)}$ and James (13).

Five frames $(0.5 \mathrm{~g})$ of each samples was wrapped in a porous paper (what man No. 1 filter paper). The weight wrapped sample was put in a soxhelt enflux flask containing $200 \mathrm{ml}$ of petroleum ether. The upper end of the reflux flask was connected to a condenser. By heating the solvent in the flask through electro-thermal heater, it vaporizes and condensed into the reflux flask. Soon the wrapped sample was completely immersed in the solvent and remained in contact with it until the flask filled up and siphoned over thus carrying oil extract from the sample down to the boiling flask. This process was allowed on repeatedly for about 4 hours before the defatted sample was removed and reserved for crude fiber analysis. The solvent was recovered and the extracting flask with its oil content was dried in the oven at $60^{\circ} \mathrm{C}$ for 3 minutes (i.e. to remove any residual solvent). After cooling in a desicator, the flask was reweighed.

By difference, the weight of fat (oil) extraction was determined and expressed as a percentage of the sample weight, it was calculated as:

$$
\% \text { Fat }=\frac{\mathrm{W}_{2}-\mathrm{W}_{1}}{\text { Weight of Sample }} \times \frac{100}{1}
$$

Where:

$\mathrm{W}_{1}=$ Weight of empty extraction flask

$\mathrm{W}_{2}=$ Weight of flask and oil extract

\subsubsection{Determination of Crude Fibre}

This was determined by the Wende method ${ }^{(13)}$. Five grammes $(5 \mathrm{~g})$ of each sample were defatted (during fat analysis). The defatted sample was boiled in $200 \mathrm{ml}$ of $1.25 \%$ $\mathrm{H}_{2} \mathrm{SO}_{4}$ solution under reflux for 30 minutes. After that, the samples were washed with several portions of hot (boiling) water using a two-fold muslin cloth to trap the particle. The washed samples were carefully transferred quantitatively back to the flask and $200 \mathrm{ml}$ of $1.25 \% \mathrm{NaOH}$ solution was added to it. Again, the samples were boiled for 30 minutes and washed as before with hot water. Then, they were very carefully transferred to a weighed porcelain crucible and dried in the oven at $105^{\circ} \mathrm{C}$ for 3 hours. After cooling in a desicator, they were reweighed $\left(\mathrm{W}_{2}\right)$ and then put in a muffle furnace and burn at $550^{\circ} \mathrm{C}$ for 2 hours (until they become ash). After, they were cooled in a desicator and reweighed.

The crude fiber content was calculated gravimetrically as:

$$
\% \text { Crude Fiber }=\frac{\mathrm{W}_{2}-\mathrm{W}_{3}}{\mathrm{Wt} \text { of Sample }} \times \frac{100}{1}
$$

Where:

$\mathrm{W}_{2}=$ Weight of crucible + sample after washing drying in oven

$\mathrm{W}_{3}=$ Weight of crucible of sample as ash

\subsubsection{Determination of Total Ash}

This was done using the furnace incineration gravimetric method ${ }^{(15)}$. A measured weight $(5 \mathrm{~g})$ of each fruit sample was put in a precious weighed porcelain crucible. The sample in crucible was put in a muffle furnace set at $550^{\circ} \mathrm{C}$ and allowed to burn for 2 - 3 hours (until the sample become a gray ash). The sample in crucible was very carefully removed from the furnace (taking care not to allow air blow the ash away) and cooled in a desicator. It was reweighed by difference, the weight of ash was obtained and in percentage. It was given by the formula:

$$
\% \text { Ash }=\frac{\mathrm{W}_{2}-\mathrm{W}_{1}}{\text { Wt of Sample }} \times \frac{100}{1}
$$

Where:

$\mathrm{W}_{1}=$ Weight of crucible

$\mathrm{W}_{2}=$ Weight of empty crucible

\subsubsection{Determination of Carbohydrate}

The carbohydrate content was calculated by difference as the Nitrogen Free Extractive (NFE), a method separately described by Pearson ${ }^{(14)}$ and James ${ }^{(13)}$. The NFE was by:

$$
\% \text { NFE }=100-\%(a+b+c+d+e)
$$

Where:

$\mathrm{a}=$ Protein

$\mathrm{b}=$ Fat

$\mathrm{c}=$ Fibre

$\mathrm{d}=$ Ash

$\mathrm{e}=$ Moisture

\subsubsection{Determination of Moisture Content}

A moisture content was determined by the gravimetric method ${ }^{(12)}$. A measured weight of each sample $(5 \mathrm{~g})$ was 
weighed into a moisture can. The can and its sample content were dried in the oven at $105^{\circ} \mathrm{C}$ for 3 hours. In the first instance, it was cooled in a desicator and reweighed. The weight was recorded while the sample was returned to the oven for further drying. The drying, cooling and weighing was contained repeatedly until a constant was obtained.

By the difference, the weight of moisture loss was determined and expressed as a percentage. It was calculated as shown below:

$$
\% \text { Moisture }=\frac{\mathrm{W}_{2}-\mathrm{W}_{3}}{\mathrm{~W}_{2}-\mathrm{W}_{1}} \times \frac{100}{1}
$$

Where:

$\mathrm{W}_{1}=$ Weight of empty moisture

$\mathrm{W}_{2}=$ Weight of can before drying

$\mathrm{W}_{3}=$ Weight of can + sample after drying to a constant weight

\subsection{Preparation of Indigenous Dishes Using Pumpkin Leaves, Pulp and Seeds}

The dishes to prepare are:

1. Pumpkin Soup

2. Pumpkin Pottage Yam

3. Pumpkin Roasted Seeds

Table 1. Pumpkin Soup Ingredients Using Pumpkin Leaves (PLS)

\begin{tabular}{ll}
\hline Ingredients & Grams (g) \\
\hline Cray fish & 45 \\
Salt & 15 \\
Stock fish & 75 \\
Meat (Beef) & 405 \\
Onion & 140 \\
Pumpkin leaves & 350 \\
12 tea spoons of palm oil & 60 \\
\hline
\end{tabular}

\subsubsection{Method}

1. Measure out the ingredients

2. Boil the cut meat with water and add salt, pepper, onion and crayfish to give the meat taste. Stockfish is also included.

3. When the meat and stockfish is down put palm oil

4. Add water if it has reduced from the quantity that should be enough

5. Add pumpkin leaves and then stair it very well
6. After 2 minutes bring down the pot of soup

Table 2. Pottage Yam Ingredients Using Pumpkin Pulp (PPP)

\begin{tabular}{ll}
\hline Ingredients & Grams (g) \\
\hline Peeled yam & 450 \\
Crayfish & 10 \\
Teaspoon of paom oil & 75 \\
Salt & 15 \\
Scooped out pumpkin pulp (cooked) & 1750 \\
Onion & 140 \\
Pepper & 5 \\
\hline
\end{tabular}

\subsubsection{Method}

1. Peel the yam, cut into small sizes

2. Wash and put into a pot with water

3. Ass spices, salt, pepper, crayfish, onion and palm oil

4. Add the already scooped out pulp into the almost done porriadge yam and stir very well

5. Add any vegetable of your choice

6. After 2 minutes put down the pot of pottage yam.

\subsubsection{Roasted Seeds (RPS) \\ Ingredients \\ Salt and pumpkin only}

\subsubsection{Method}

1. Bring out the seeds from the pulp

2. Rinse them in water

3. Apply and rob salt on them

4. Allow for some time to absorb the salt, this is to give the seeds taste

5. Put the seeds on frying pot and begin to turn them

6 . The heat temperature should be moderate to avoid boring of the seeds. When done put down the frying pot.

\subsubsection{Sensory Evaluation}

Sensory evaluation was carried out using a 9 point hedonic scale in which 25 panelist were presented with product and asked to evaluate their sensory characteristics based on colour, flavor, texture and degree of acceptability. After the sensory evaluation, the produce was statistically analyzed to determine the best product among the different dishes prepared.

\subsubsection{Data Analysis}

The data collected was calculated. The essence of the statistical analysis was to determine if there were significant differences among the dishes. Analysis of Variance (ANOVA) was used to determine the mean scores of the sensory scores which Duncan new Multiple Range Test ${ }^{(16)}$ was to determine if there were significant difference.

Table 3. Proximate Composition of Pumkpin Seeds, Leaves And Pulp as Consumed

\begin{tabular}{lllllll}
\hline Sample & Moisture (\%) & Ash (\%) & Fiber (\%) & Fat (\%) & Protein (\%) & Carbohydrate (\%) \\
\hline Raw Seed & $7.86 \pm 0.01$ & $4.80 \pm 0.0071$ & $3.630 \pm 0.100$ & $41.41 \pm 0.0141$ & $29.65 \pm 0.0071$ \\
Roasted Seed & $5.3 \pm 10.0100$ & $4.86 \pm 0.0071$ & $3.71 \pm 0.0158$ & $43.28 \pm 0.6976$ & $28.74 \pm 0.0458$ & $12.63 \pm 0.0173$ \\
Leaves & $68.23 \pm 0.0122$ & $2.34 \pm 0.0100$ & $13.71 \pm 0.015$ & $1.53 \pm 0.0100$ & $4.82 \pm 0.0158$ \\
Cooked Pulp & $90.74 \pm 0.0200$ & $1.18 \pm 0.0100$ & $0.66 \pm 0.0100$ & $1.13 \pm 0.0100$ & $1.23 \pm 0.0458$ & $5.30 \pm 0.035$ \\
Uncooked Pulp & $89.62 \pm 0.0100$ & $1.25 \pm 0.0100$ & $0.86 \pm 0.0100$ & $0.92 \pm 0.0100$ & $2.36 \pm 0.0071$ & $4.86 \pm 0.0071$ \\
\hline
\end{tabular}

Mean \pm Standard Deviation of three replications 
Table 3 presents the proximate composition of pumpkin seeds, leaves and pulp as consumed.

The moisture content of the roasted seeds $(5.31 \%)$ is lower than the raw $(7.86 \%)$. The pulp does not show much difference in moisture content between the cooked pulp $(89.74 \%)$ and uncooked pulp $(89.62 \%)$. The leaves have a moisture content of $68.23 \%$, pumpkin leaves have high fiber content $(13.71 \%)$ than the raw and roasted seed $(3.71 \%)$ and $3.63 \%)$ respectively. The pulp has the lowest $(0.66 \%)$ cooked and $(0.86 \%)$ uncooked pulp. This result gotten is in line with previous work done by Platt (1985) except the fiber content of the leaves that fall off the range. The protein was found more in the seeds with $(29.65 \%)$ raw and $(28.74 \%)$ roasted. The next with high protein is the leaves with $(4.82 \%)$, the pulp ranged from $(2.23 \%-2.36 \%)$ for cooked and uncooked. The roasted seeds of pumpkin have the highest for $(42.28 \%)$ and the raw has about $(39.41 \%)$. The leaves have small quantity of fox $(1.53 \%)$ cooked pulp $(1.13 \%)$ and uncooked pulp $(0.92 \%)$. The seed have more carbohydrate ranged from $(12.63 \%)$ raw to $(14.08 \%)$ roasted than the leaves $(9.30 \%)$. The pulp is the least with $(5.17 \%)$. The ash content of pumpkin samples is highest in the raw roasted seeds $(4.80 \%)$ and $(4.86 \%)$ respectively. The leaves contain $(2.34 \%)$ ash. The pulp is least among the sample with $1.18 \%-1.25 \%$.

Table 4. Sensory Properties of the Pumpkin Sample

\begin{tabular}{|c|c|c|c|c|}
\hline Sample & Colour & Flavor & Texture & General Acceptability \\
\hline PPP & $8.68^{a} \pm 0.73$ & $8.56^{\mathrm{a}} \pm 1.04$ & $8.28^{\mathrm{ab}} \pm 1.06$ & $8.48^{\mathrm{a}} \pm 0.77$ \\
\hline PLS & $8.32^{b} \pm 0.69$ & $8.40^{\mathrm{a}} \pm 0.82$ & $8.40^{\mathrm{a}} \pm 0.87$ & $8.40^{\mathrm{a}} \pm 0.91$ \\
\hline RPS & $7.72^{c} \pm 1.35$ & $7.56^{b} \pm 1.53$ & $7.52^{b} \pm 2.51$ & $6.60^{\mathrm{b}} \pm 1.66$ \\
\hline
\end{tabular}

Mean \pm Standard Deviation of 25 replications

$\mathrm{PPP}=$ Pumpkin pulp pottage

PLS = Pumpkin leave soup

RPS $=$ Roasted pumpkin seed

Table 4 presents the sensory properties of the pumpkin leaves, pulps and seeds. The result of sensory evaluation showed that samples pumpkin pulp pottage (PPP), pumpkin leaves soup (PLS) and roasted pumpkin seeds (RPS) are significantly different $(\mathrm{P}<0.05)$ for colour, however, PPP were preferred more and RPS were the least preferred. In the table as well, the result presented showed that PPP were preferred more and RPS were the least preferred in flavor. Samples PPP and PLS were statistically similar but significantly different $(\mathrm{P}<0.05)$ from RPS. Samples PLS are significantly different $(\mathrm{P}<0.05)$ from $\mathrm{PPP}$ and RPS for texture, PLS were preferred more and RPS were the least preferred in texture. Samples PPP and PLS are statistically similar but significantly different $(\mathrm{P}<0.05)$ from RPS in generally acceptability. However, all the samples has high mean scores.

\section{Discussion}

\subsection{Proximate Composition}

The moisture content of the roasted seed $5.31 \%$ is lower than the raw $(7.86 \%)$. This was as a result of heat subjected to the seed during roasting of the seeds ${ }^{(17)}$. The pulp does not show much difference in moisture content between the cooked pulp (89.74\%) and uncooked pulp (89.62\%). The high moisture content in the pulp can expose them to danger of bacteria and mould which produce undesirable changes. The leaves have a moisture content of $68.23 \%$. Pumpkin leaves have high fiber content $(13.71 \%)$ than the raw and roasted seeds $(3.71 \%$ and $3.63 \%)$ respectively. The pulp has the lowest $(0.66 \%)$ cooked and $(0.86 \%)$ uncooked pulp. The result gotten is in line with previous work done by Platt
(1985) except the fiber content of the leaves that fall off the range.

The protein was found more in the seeds with $(29.65 \%)$ raw and $(28.74 \%)$ roasted. The result of heat applied during roasting which tends to denature the protein molecules ${ }^{(16)}$. Next with high protein is the leaves with $(4.82 \%)$, the pulp ranged from $(2.23 \%-2.36 \%)$ for cooked and uncooked. The roasted seeds of pumpkin have the highest for $(42.28 \%)$ and the raw has about (39.41\%). Therefore, seeds having high level of oil can be used or considered as good source of vegetable oil $^{(18)}$.

\subsection{Sensory Properties}

The sensory result samples PPP, PLS and RPS are significantly different $(\mathrm{P}<0.05)$ for colour. Under flavor, PPP, PLS and RPS are significantly different but PPP and PLS are significantly different $(\mathrm{P}<0.05)$ from RPS. Samples PPP, PLS and RPS are significantly different $(\mathrm{P}<0.05)$ for texture. PPP and PLS samples have no significant difference and are generally acceptable but both are significantly different from RPS.

\section{Conclusion}

This work has provided a baseline information on the proximate composition of pumpkin leaves, pulps and seeds. Pumpkin has high nutritive value and thus can be used in treatment of pregnant women and children affected by infestation of tape worms. It is also used in promoting prostate health. So adequate and frequent consumption of pumpkin recipes can be used to increase a better nutrition and health. 


\section{References}

[1] Heinermon's (2000): Encyclopedis of Fruits, vegetables and herbs.

[2] George R.A.T (1999): Vegetable seed production. Longman, London.

[3] Bates D.M, Robinson R.W (1998): Plant resources of tropical African. Backhuy's Publishers, Netherland.

[4] Andrew Chevalier (2000): The Encyclopedia of Medicinal Plants.

[5] Michael, Orsolek D, George L (2000): "Pumpkin Production". Agricultural Alternatives.

[6] Ngwemme Chiegumira (2000): Plant resources of tropical Africa. Backhuy's Publishers, Netherland.

[7] Pratt S (2004): Super foods RX fourteen foods that will change your life. New York Harper Colling.

[8] Pumpkin (2007): In Encyclopedia Britanica. Retrieved November 28, 2007 from Encyclopedia Britanica Online.

[9] Ensminger A.H, Esminger M.K.J (1998): Food for Health: A Nutrition Encyclopedia. Olouis, California, Pegus Press.

[10] Oke O.L (2000): Chemical studies on some Nigerian vegetables. Trop. Science, Vill. Pp. 20 - 25.

[11] Tyler Herbsa, Sharon (2001): The New food lover's companion, $3^{\text {rd }}$ ed. Barron Pumpkin seed oil. 14 Feb., 2008.

[12] Zubair H, Abdel-Fattah A.A, Abdel Caitiff (1997): Efficacy of Simvastation and pumpkin seed oil in the management of dietary-induced hypercholest erolenmia.

[13] James C.S. (1995). Analytical Chemistry of Foods 1 edn, Chapman and Hall New York.

[14] Pearson D (1991): Pearson's composition and analysis of foods. Co. Published in the United States with John Wiley and Sons Inc., New York.

[15] A.O.A.C (1990): Official method of analysis, $5^{\text {th }}$ edition, Sidney Williams (ed.), Association of Official Analytical Chemists Inc, Arlington.

[16] Ihekoronye, A.I. \& Ngoddy, P.O. (1985). Integrated Food Science and Technology, for the Tropics. Macmillan Publishing Ltd. London p.386.

[17] Amaral J.S, Casal S, Seabara R.M (2006): Effects of roasting on nut/seeds lipids. J. Agric. Food Chem. 2006 Feb. 22:54(4) $12: 15-21$.

[18] The Pumpkin Patich (2007): Halloween Online, 19 Feb. 2008 (hpp:www.pumpkinpatch.com) 